\title{
Marine research in the Iberian Peninsula: A pledge for better times after an economic crisis ${ }^{\text {th }}$
}

\author{
Angel Borja ${ }^{\mathrm{a}, *}$, Joao-Carlos Marques ${ }^{\mathrm{b}}$, Celia Olabarria ${ }^{\mathrm{c}}$, Victor Quintino ${ }^{\mathrm{d}}$ \\ a AZTI-Tecnalia, Herrera Kaia, Portualdea s/n, 20110 Pasaia, Spain \\ b IMAR - Institute of Marine Research, Department of Life Sciences, Faculty of Sciences and Technology, University of Coimbra, 3004-517 Coimbra, Portugal \\ c Departamento de Ecoloxía e Bioloxía Animal, Facultade de Ciencias Experimentais, Universidade de Vigo, 36310 Vigo, Spain \\ d Departamento de Biologia E CESAM, Universidade de Aveiro, Campus Universitário, 3810-193 Aveiro, Portugal
}

\section{A R T I C L E I N F O}

Article history:

Received 27 April 2013

Received in revised form 2 July 2013

Accepted 6 July 2013

Available online 18 July 2013

\section{Keywords:}

Marine Research

Marine Biology

Iberian Peninsula

Scientific Productivity

Past Trends

Future Challenges

\begin{abstract}
A B S T R A C T
The "17th Iberian Symposium of Marine Biology Studies" took place in San Sebastian (Spain), in September 2012. This contribution is an introduction to a special issue collating the most challenging papers submitted by Portuguese and Spanish scientists to the symposium. The text was structured as a novel, with the three main parts of a novel: (i) Setup: a historical context, from old times to the 1970's. This part presents the main Iberian scientific contribution to marine science, since the 15th Century, as a precedent to modern scientific research; (ii) Conflict: from the 1970 's to the economic crisis. This part presents the evolution of Iberian research production, based upon a bibliometric study, from 1974 to 2012; and (iii) Resolution: what for the future?, which shows the main challenges, proposed by the authors, to the European research initiative 'Horizon 2020', including aspects such as the need of knowledge-base for marine management, the marine research as a potential source of jobs, the ecosystem-based approach, human activities and Marine Spatial Planning, moving from fisheries to aquaculture, or global change issues, among others.
\end{abstract}

(c) 2013 Elsevier B.V. All rights reserved.

\section{Introduction}

In 1979 the first 'Iberian Symposium of Marine Biology Studies' took place in San Sebastián (northern Spain) (Niell and Ros, 1982). After 17 editions, in 2012, this symposium returned to the same place, and this Special Issue includes 23 out of the 250 contributions presented there, by Portuguese and Spanish scientists. We have structured this introductory paper as a novel, with the three main parts of a novel: (i) Setup: a historical context, from old times to the 1970's. This part presents the main Iberian scientific contribution to marine science, since the 15th Century, as a precedent to modern scientific research; (ii) Conflict: from the 1970's to the economic crisis. This part presents the evolution of Iberian research production, based upon a bibliometric study, from 1974 to 2012; and (iii) Resolution: what for the future?, which shows the main challenges, that we propose, to the European research initiative 'Horizon 2020'.

\section{Setup: a historical context, from old times to the 1970's}

The long and rich history of the Iberian Peninsula (i.e. Portugal and Spain) has reflected also in the early descriptions of marine life, by the

\footnotetext{
Given their role as Guest Editors, Borja, A., J.C. Marques, V. Quintino had no involvement in the peer-review of this article and has no access to information regarding its peer-review. Full responsibility for the editorial process for this article was delegated to Judi Hewitt.

* Corresponding author. Tel.: + 34 667174430; fax: + 34946572555

E-mail address: aborja@azti.es (A. Borja).
}

historian Pliny the Elder (Gaius Plinius Secundus, Naturalis Historiae, Liber Quartus, 1st Century AC). In the middle age, the Ripoll's Bible (in Catalonia), a valuable manuscript codex dated between 1015 and 1020, includes a map of Roman Hispania showing images of marine fish.

However, it was after the 15th Century, when Spanish and Portuguese navigators sailed to discover new lands (e.g. Bartolomeu Dias turning the Cape of Good Hope, in 1488; Cristóbal Colón, discovering America's continent, in 1492; Vasco da Gama navigating around Africa to India, from 1497 to 1499; Fernão de Magalhães and Juan Sebastián Elcano, in the first expedition circumnavigating the Earth, in 1519-1522; Andrés de Urdaneta, who discovered the fastest navigation route between Asia and America, in 1565; etc.), that these pioneers prepared the way to the future scientific expeditions in the Atlantic and Pacific Oceans, in the 18th and 19th Centuries.

In the 18th Century, the Spanish King Carlos III founded the Royal Cabinet of Natural History, which was the origin of the present Natural History Museum of Madrid, and undertook the first scientific works on marine fauna and flora. In these and immediately following times, ichthyology, oceanography and fisheries were usually studied together (Rallo and Borja, 2004). Hence, one of the most important works undertaken in the Atlantic coast of the Peninsula was the "Essay of a history of fishes and other marine productions of the coast of Galicia, arranged according to the system of Knight Linnaeus", written by José Cornide de Saavedra, and published in Madrid, in 1788. Between 1789 and 1794 the 'Malaspina expedition', commanded by Alejandro Malaspina and including many hydrographers and naturalists, circumnavigated 
the Earth, aiming to increase the scientific knowledge of botany, zoology, geology and hydrography in remote regions of America and the Pacific. These studies, together with others referring to other coasts of the Peninsula, could be considered as the start of a systematic Iberian marine scientific research. In fact, a new 'Malaspina expedition' was organized between 2010 and 2011, in a journey of 42,000 nautical miles around the world, dealing with new issues, such as biodiversity in deep waters, climate change or use of new genomic approaches in studying marine waters (Rebok, 2012).

In the 19th Century, the ultramarine 'Scientific Commission of the Pacific', an expedition to the South America Pacific coasts and on the downstream part of the Amazon River, was of particular interest; this departed in 1862, returning in 1866 with extensive observations and collected material. This expedition provided a renaissance of marine research in the last three decades of the 19th Century. Hence, in 1871, the Spanish Society of Natural History was founded, in Madrid. One of the earliest activities of the Society was to promote and to request the creation of Marine Laboratories along the Spanish coast. The plan included several visits to other European centres working in marine biology and oceanography (in particular the 'Stazione Zoologica de Napoli', in Italy). The first Marine Laboratory was created in Santander, in northern Spain, in 1886, which was integrated into the Spanish Institute of Oceanography, created in 1914 to join and coordinate the research in all the institutional marine laboratories in Spain. At the end of the 19th Century, Adolfo Navarrete y de Alcázar published the first modern Spanish texts on Oceanography (1896) and Marine Biology (1898) (Duarte et al., 2006).

As early as 1908, the Oceanographic Society of Gipuzkoa (Basque Country, northern Spain) was founded (the second oldest in the world, after that of Monaco), having in mind the development of practical and applied knowledge of the sea. In 1913, there were several considerations published by this Society, which can be accepted as valid today: "Many people believe that the sea is an endless source of marine products, and that however much that men take from it, using any kind of catchment procedures, sea richness does not become diminished and will remain forever. It is necessary to say and repeat that fish, as all the products of nature, have the risk to be exhausted" (see Rallo and Borja, 2004).

The scientific activities of these societies included oceanographic research cruises undertaken along the Spanish coasts. In parallel, in Portugal, from 1896 to 1907, the King D. Carlos I promoted and participated as naturalist in several oceanographic cruises, along the Portuguese coast. As a whole, these expeditions generated an important practical and theoretical knowledge of the marine systems, namely regarding commercial fisheries.

A number of Iberian faunistic and floristic monographs were published from mid-19th Century to mid-20th Century; e.g. crustacea (de Buen, 1886); cryptogams (Colmeiro, 1889; Lázaro-Ibiza, 1889, 1893); porifera (Ferrer-Hernández, 1914a, 1914b); molluscs (Hidalgo, 1917; Nobre, 1936); fishes (de Buen, 1942; Lozano Rey, 1928); polychaetes (Rioja, 1931); etc.

By this time, habitat conditions and other ecological aspects were included as being characteristic of the species. Nevertheless, although there are some early studies concerned with oceanography, bionomics and ecology, these disciplines acquired its present significance with Ramón Margalef (1919-2004), considered one of the fathers of modern ecology. His book 'Ecology' (Margalef, 1977) represents the hinge between the 'old Iberian marine science' and the 'new one'. Around that time (in 1979), some of Margalef's students, started to organize scientific meetings that are at the genesis of today's 'Iberian Symposium of Marine Biology Studies', the first of which took place in San Sebastián (northern Spain) (Niell and Ros, 1982). Hence, this overview introduction wants to be a tribute to all marine naturalists and scientists, who have contributed to expand the marine knowledge in the Iberian Peninsula in the past 300 years, presenting also the current research topics and future challenges.

\section{Conflict: from the 1970's to the economic crisis}

After the reinstitution of democracy in Portugal and Spain (in 1970 's), science in general and marine science in particular, experienced a rapid growth, with the creation of five faculties of marine science and several research institutes in Spain (Delgado et al., 1999). In Portugal, a research funding scheme was then initiated and evolved from calls sponsoring persons and research projects only, to its current status, where PhD programs, multi-institutional research centres and associate laboratories dedicated to Marine Science are all part of the state funding system, under international assessment. Iberian marine research benefited from Portuguese and Spanish adhesion to the European Community, in 1986, and the accession to European research funds, such as the thematic programme MAST (Marine Science and Technology), and the successive research Framework Programmes. In addition, national governments invested also in training, research infrastructures and oceanographic vessels (Delgado et al., 1999; Duarte et al., 2006).

This resulted in an increasing presence of Iberian marine research in international scientific journals (Duarte et al., 2006). In order to get an objective view of the current scientific production in the Iberian Peninsula, the Elsevier's search tool 'SCOPUS' was consulted on 3rd February 2013. As this special issue deals with the 'Iberian Symposium on Marine Biology Studies', the terms "marine biology", or "marin*", or "coast", or "estuar", appearing in the abstract, title or keywords within articles or reviews, were searched together with the affiliation of the authors in Portugal or Spain. The search was only in the Science Citation Index (SCI) journals. This selection can show differences with previous bibliometric studies in the area (e.g. Duarte et al., 2006), in which terms such as 'oceanography', 'engineering' and others were used also.

Hence, over a total of 516,114 papers published in the world under the topics selected, 21,565 papers were published in Iberia (4.2\%), for the period 1974-2012. Spain is in the 9th position and Portugal in 21st position of the countries publishing in marine biology (Fig. 1), which is much higher than the corresponding position in population (27th and 81st, respectively). In fact, the progress was very important, since they occupied the positions 27th and 72nd, in 1980; 23rd and 70th, in 1985; 15th and 43rd, in 1990; 12th and 34th, in 1995 and 9th and 26 th, in 2000 , respectively.

The number of SCI manuscripts per year was very small $(<10)$ in the 1970's, increasing from 18, in 1980, to 251, in 1995 (Fig. 2). In 1996 a sudden increase occurred (to 469 manuscripts) and then an exponential increase can be observed until $>2000$ manuscripts per year, after 2010 (Fig. 2).

The authors who have published more than 70 papers each during that period of time are listed in Table 1. From 21 authors, 8 are Portuguese and 13 Spanish. The first most productive author is the Spanish scientist C.M. Duarte, and the next 5 most productive authors are Portuguese. The authors work mainly in universities (12, including 6 Portuguese and 6 Spanish), followed by the Spanish CSIC ('Consejo Superior de Investigaciones Científicas', with 6 centres), 2 Portuguese institutes, and 1 Spanish private research foundation (AZTI-Tecnalia) (Table 1). The increase in papers after 2004 could be attributed, among other factors, to two main issues: (i) the investment of research after the 'Prestige' oil spill, in 2002 in northern Spain, which, after an initial lack of research coordination (Freire et al., 2006), supposed an international cooperation in the investigation of the effects; and (ii) the relevant role of Portuguese and Spanish scientists in the implementation of the Water Framework Directive (WFD, 2000/60/EC), and the subsequent development of different ecological assessment methods (Birk et al., 2012).

The most cited authors (>10,000 citations each) are 3 Spanish scientists: D. Barceló, C.M. Duarte and J.O. Grimalt, all of them working at the CSIC (Table 1$)$. The highest $\mathrm{H}_{\text {index }}$ values $(>30)$ are shown by Spanish scientists, all of them working at the CSIC (the abovementioned authors and J.M. Gasol, J.M. Bayona and J. Albaigès), excepting A. Borja, 


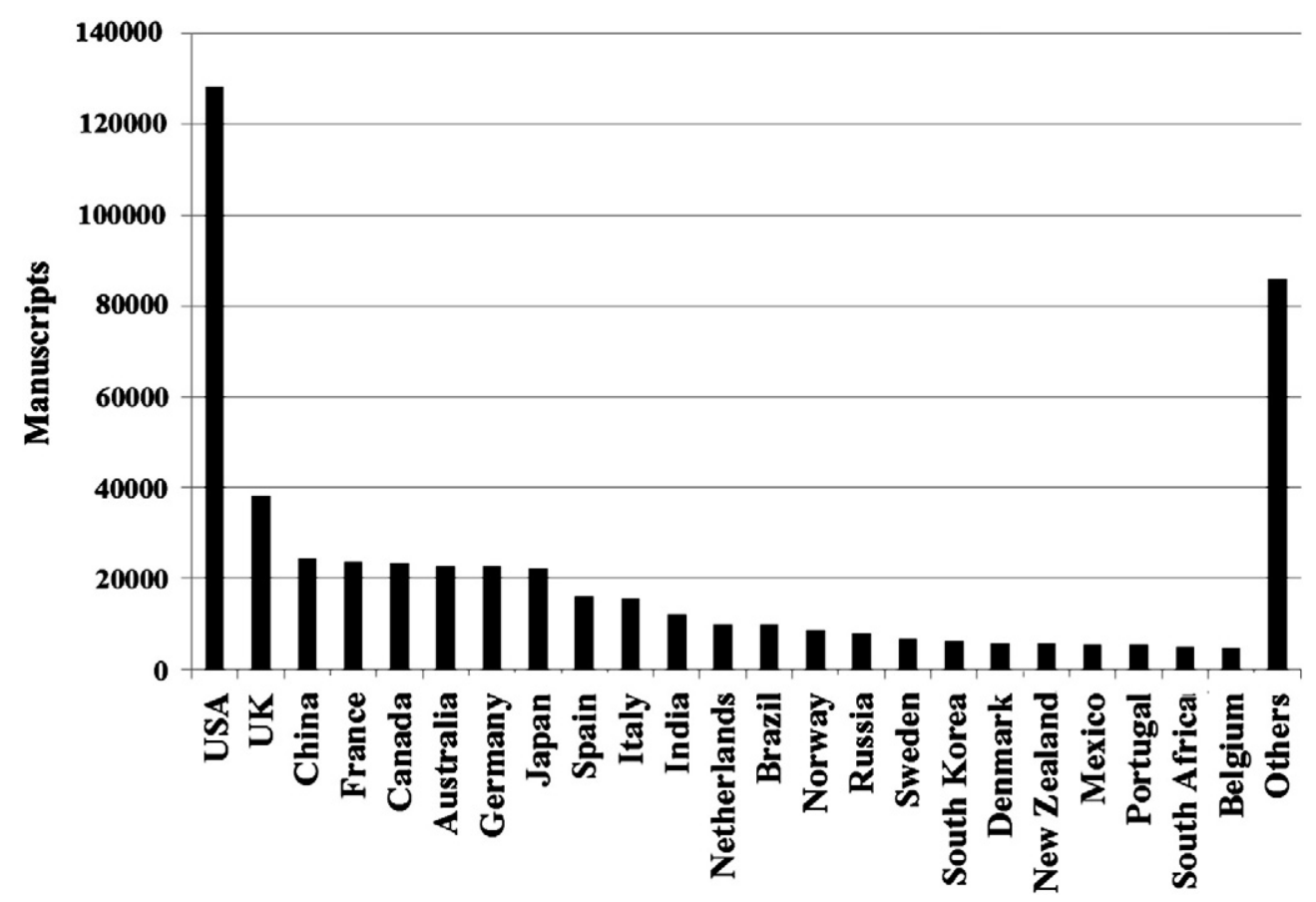

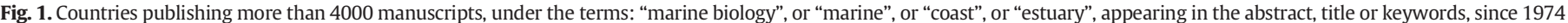
(consulted in SCOPUS, on 3rd February 2013).

who works at AZTI-Tecnalia, and by a Portuguese, J.C. Marques, working at IMAR - Institute of Marine Research, University of Coimbra (Table 1).

From the total of papers published in the period 1974-2012, Iberian authors have published at least 25 papers in 160 different SCI journals, representing $45 \%$ of the total papers (Table 2 ). The most selected journal was 'Estuarine, Coastal and Shelf Science', with 506 papers; then, 'Marine Ecology Progress Series', with 435; and 'Marine Pollution Bulletin', with 372 (Table 2). A Spanish journal, 'Scientia Marina', published by the CSIC, occupies the 5th place, with 310 papers (Table 2). It is of note that highly ranked SCI journals, such as 'Nature' and 'Science', have only 38 and 32 papers, respectively, from Iberian authors in the selected topics (Table 2).

From the keywords used by Spanish and Portuguese scientists, it can be seen (Table 3 ) that the most frequent topics, both in the Atlantic Ocean and the Mediterranean Sea, are: (i) biodiversity, taxonomy and community structure (different taxonomic groups studied, etc.), which appear in $20.8 \%$ of the papers; (ii) environmental research (water pollution, environmental monitoring, etc.), in 18.3\%; (iii) estuarine and coastal environments, in 11\%; (iv) oceanography (seawater, salinity, upwelling, modelling, etc.), in 9.41\%; (v) effects of pollution (bioaccumulation,

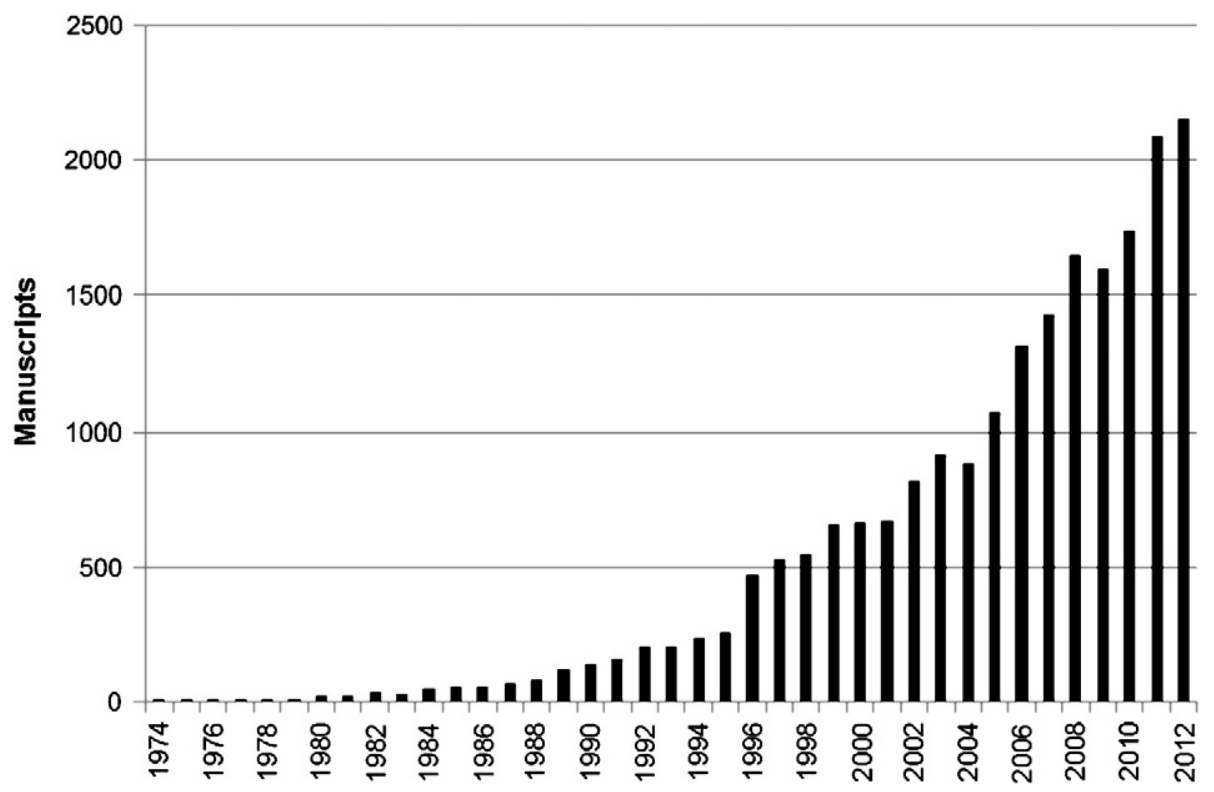

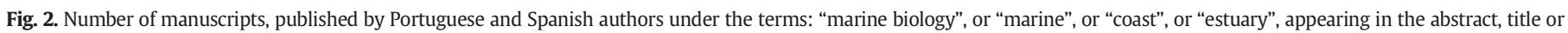
keywords, since 1974 (consulted in SCOPUS, on 3rd February 2013). 
Table 1

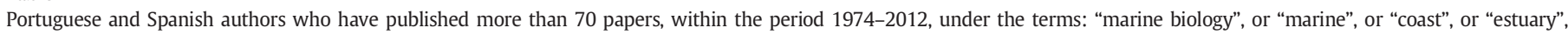

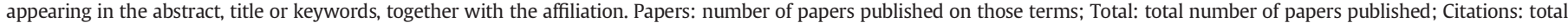
citations received by the authors; $\mathrm{H}_{\text {index }}$ of the authors (consulted in SCOPUS, on 3rd February 2013). Key: TM: too many to be consulted.

\begin{tabular}{|c|c|c|c|c|c|c|}
\hline Authors & Institution & Country & Papers & Total & Citations & $\mathrm{H}_{\text {index }}$ \\
\hline Duarte, CM & CSIC-IMEDEA & Spain & 196 & 422 & 14230 & 53 \\
\hline Vale, C & Portuguese Institute of Sea and Atmosphere & Portugal & 149 & 178 & 2686 & 25 \\
\hline Pardal, MA & U. Coimbra & Portugal & 141 & 178 & 2752 & 29 \\
\hline Marques, JC & U. Coimbra-IMAR & Portugal & 138 & 185 & 3268 & 31 \\
\hline Cabral, HN & U. Lisbon & Portugal & 137 & 204 & 2144 & 25 \\
\hline Costa, MJ & U. Lisbon & Portugal & 110 & 145 & 1744 & 23 \\
\hline Albaiges, J & CSIC & Spain & 109 & 197 & 5335 & 30 \\
\hline Prego, R & CSIC-IIM & Spain & 103 & 138 & 1959 & 24 \\
\hline Botana, LM & U. Santiago de Compostela & Spain & 97 & 231 & 2876 & 26 \\
\hline Guedes-Soares, C & Instituto Superior Tecnico & Portugal & 96 & 435 & 3709 & 27 \\
\hline Sánchez-Arcilla, A & U. Politécnica de Cataluña & Spain & 95 & 129 & 727 & 13 \\
\hline Borja, A & AZTI-Tecnalia & Spain & 90 & 133 & 3390 & 31 \\
\hline Medina, $\mathrm{R}$ & U. Cantabria & Spain & 87 & 122 & 684 & 14 \\
\hline Bayona, JM & CSIC & Spain & 85 & 255 & 5957 & 36 \\
\hline Gasol, JM & CSIC-ICM & Spain & 84 & 158 & 5072 & 38 \\
\hline Grimalt, JO & CSIC-IDAEA & Spain & 84 & 397 & 10342 & 49 \\
\hline Barceló, D & U. Girona & Spain & 80 & 776 & $\mathrm{TM}$ & 70 \\
\hline Gómez Parra, A & U. Cádiz & Spain & 78 & 102 & 1632 & 24 \\
\hline Duarte, AC & U. Aveiro & Portugal & 77 & 316 & 2921 & 26 \\
\hline Bebianno, MJ & U. Algarve & Portugal & 73 & 126 & 2693 & 24 \\
\hline DelValls, TA & U. Cádiz & Spain & 72 & 121 & 1735 & 25 \\
\hline
\end{tabular}

eutrophication, etc.), in 3.81\%; (vi) fisheries and aquaculture, in 3.29\%; (vii) genetics and genomics (molecular and nucleotide sequence, etc.), in $3.27 \%$; and (viii) climate change, in $1.07 \%$.

Despite of the number of published papers in recent years, since 2009 the Iberian countries have experienced an important economic crisis, leading to cut the operational budgets of statutory bodies and universities (in some cases more than 50\%). This has resulted in a reduction of monitoring networks, environmental protection and nature conservation (Borja and Elliott, 2013), a reduction of projects funding, PhD students and personnel in universities and research centres and, probably in the near future, will lead to a reduction of the scientific production and publications.

\section{Resolution: what for the future?}

In this panorama of economic crisis, the European programme 'Horizon 2020' (European Commission, 2012), together with some national initiatives, will be the main instrument for Iberian countries to maintain scientific excellence in the period 2014-2020. This research will be rooted in that which is being done by the authors leading the list in the previous section, including ecotoxicology issues (biological responses to pollutants; adaptability of organisms; etc.), analytic organic chemistry (including pharmaceuticals, new analytical methodologies, etc.), reconstruction of past climate and ecology, molecular analysis of marine microbial food-webs, seagrass and other coastal vegetation, carbon dynamics in land-ocean exchange, functioning of coastal food-webs in relation to hydrography and small-scale physical processes, etc. This research will provide continuation in excellence. But, in addition to those, which could be the main challenges for Iberian marine research in this period? We think that, at some extent, they can be similar to the marine research questions prioritized in several surveys to scientists made recently by Rudd and Lawton (2013), at global scale; Rees et al. (2013), in the United Kingdom; Fissel et al. (2012), in Canada; or the International Council for the Exploration of the Sea (ICES) Draft Science Plan (2014-2018), which we have compared with the Iberian marine research that we propose in the bullets below (Table 4). All of them focus on main challenges regarding global change, biodiversity, management, integrative assessment, conservation or understanding of human impacts on marine ecosystems, among others. Hence, we think that the main challenges for Iberian research are related to those global issues identified everywhere.

\subsection{Marine management: a knowledge-based issue}

It is well known that research is needed to inform, provide support for and implement existing and future European policies, which must, in any case, encompass different perspectives and apprehensions and account for: (i) the search for human well-being and the maintenance of human health and safety; (ii) the attempt of using marine ecosystem in an ecologically sustainable way; and (iii) the tolerance of these ecosystems to increasing human population pressures and demand for wealth creation (for instance to access sea bottom resources after the United Nations completion of countries continental shelf extension process) (Marques et al., 2009). Hence, knowledge should be transferred towards development of evidence-based policy regulation and management (Minster and Connolly, 2006). Adoption of a knowledge-based approach is required in the elaboration of a range of European maritime policies, whether sectoral (research, energy, fisheries, transport, security) or general (European Maritime Policy). A knowledge-based approach is also required for the implementation of the different Environmental Action Plans and associated thematic strategies, research framework programmes and directives (e.g. Marine Strategy Framework Directive (MSFD, 2008/56/EC), WFD, Common Fisheries Policy, Integrated Coastal Zone Management (ICZM), Marine Spatial Planning and Coastal Management Directive, Natura 2000, etc.). Strengthening the science-base of these and related policies should be an inherent requirement in their implementation (Minster and Connolly, 2006).

\subsection{Marine research: a source of jobs?}

The European Maritime Policy recognises that the maritime industries and services encompass a wide range of sectoral economic activities, from shipbuilding to shipping and ports, to fisheries and aquaculture, to recreational activities and tourism, to offshore energy exploration and extraction, and to a large number of related technical and economic services. Now, with the world economy facing a deep crisis, perhaps this marine environmental legislation can be a source of technological development and job opportunity in a range of marine sectors. At present, marine economic activities in Iberian mainly focus on tourism and fisheries/aquaculture. We need more technological development (research, scientific-technical, oceanography, exploitation of new energy sources, etc). Hence, as stated by Borja (2011), marine researchers must provide information to these sectors on which different issues 
Table 2

Science Citation Index journals in which Iberian authors have published at least 25 manuscripts, within the period 1974-2012 (consulted in SCOPUS, on 3rd February 2013).

\begin{tabular}{|c|c|c|c|c|c|c|c|c|}
\hline Journal & Papers & $(\%)$ & Journal & Papers & $(\%)$ & Journal & Papers & $(\%)$ \\
\hline Estuarine Coastal and Shelf Science & 506 & 2.35 & Journal of Applied Ichthyology & 62 & 0.29 & Harmful Algae & 38 & 0.18 \\
\hline Marine Ecology Progress Series & 435 & 2.02 & Environmental Microbiology & 60 & 0.28 & Journal of Applied Phycology & 38 & 0.18 \\
\hline Marine Pollution Bulletin & 372 & 1.73 & Marine Policy & 59 & 0.27 & Polar Biology & 38 & 0.18 \\
\hline Hydrobiologia & 317 & 1.47 & Water Science and Technology & 58 & 0.27 & Revista de Obras Públicas & 38 & 0.18 \\
\hline Scientia Marina & 310 & 1.44 & IFAC Proceedings Volumes IFAC P & 57 & 0.26 & Bulletin of Marine Science & 38 & 0.18 \\
\hline Journal of Coastal Research & 257 & 1.19 & Marine Chemistry & 57 & 0.26 & Geologica Acta & 37 & 0.17 \\
\hline J. Marine Biological Association UK & 254 & 1.18 & Botanica Marina & 56 & 0.26 & Ecotoxicology & 36 & 0.17 \\
\hline Marine Biology & 210 & 0.97 & Journal of Environmental Radioactivity & 56 & 0.26 & Marine Micropaleontology & 36 & 0.17 \\
\hline Aquaculture & 200 & 0.93 & Aquatic Toxicology & 56 & 0.26 & Aquatic Conserv. Mar. \& Fresh. Ecosystems & 36 & 0.17 \\
\hline Science of the Total Environment & 197 & 0.91 & Ecological Modelling & 56 & 0.26 & Geological Society Special Publication & 36 & 0.17 \\
\hline Journal of Marine Systems & 171 & 0.79 & Water Research & 56 & 0.26 & Environmental Geology & 36 & 0.17 \\
\hline J. Exp. Marine Biology and Ecology & 169 & 0.78 & Diseases of Aquatic Organisms & 55 & 0.26 & Oceanologica Acta & 36 & 0.17 \\
\hline Chemosphere & 163 & 0.76 & Environment International & 54 & 0.25 & Fresenius Environmental Bulletin & 36 & 0.17 \\
\hline Fisheries Research & 161 & 0.75 & Journal of Coastal Conservation & 53 & 0.25 & J. Radioanalytical and Nuclear Chemistry & 35 & 0.16 \\
\hline Palaeogeography Palaeoclimatology & 157 & 0.73 & Tetrahedron & 53 & 0.25 & Crustaceana & 35 & 0.16 \\
\hline Plos One & 154 & 0.71 & Earth and Planetary Science Letters & 53 & 0.25 & Journal of Molluscan Studies & 34 & 0.16 \\
\hline Continental Shelf Research & 144 & 0.67 & Geophysical Research Letters & 52 & 0.24 & Journal of Archaeological Science & 34 & 0.16 \\
\hline Boletín Instituto Español Oceanografía & 141 & 0.65 & Journal of Natural Products & 52 & 0.24 & Atmospheric Research & 34 & 0.16 \\
\hline Proc. Coastal Engineering Conference & 139 & 0.64 & Quaternary International & 52 & 0.24 & Molecular Phylogenetics and Evolution & 33 & 0.15 \\
\hline Journal of Plankton Research & 134 & 0.62 & FEMS Microbiology Ecology & 52 & 0.24 & Acta Geologica Hispanica & 33 & 0.15 \\
\hline Marine Environmental Research & 131 & 0.61 & Journal of Environmental Monitoring & 51 & 0.24 & Journal of Iberian Geology & 33 & 0.15 \\
\hline Marine Geology & 125 & 0.58 & Tetrahedron Letters & 51 & 0.24 & International Journal of Climatology & 33 & 0.15 \\
\hline Coastal Engineering & 121 & 0.56 & Geobios & 51 & 0.24 & Biological Conservation & 33 & 0.15 \\
\hline Ciencias Marinas & 119 & 0.55 & Bull. of Env. Contamination and Toxicol. & 51 & 0.24 & International Journal of Remote Sensing & 33 & 0.15 \\
\hline ICES Journal of Marine Science & 115 & 0.53 & Talanta & 51 & 0.24 & Journal of Parasitology & 33 & 0.15 \\
\hline Environmental Pollution & 110 & 0.51 & Analytical and Bioanalytical Chemistry & 51 & 0.24 & Cretaceous Research & 33 & 0.15 \\
\hline Sedimentary Geology & 108 & 0.50 & Oceans 2011 I.E. Spain & 49 & 0.23 & Proc. Int. Off. \& Polar Engineering Conf. & 32 & 0.15 \\
\hline Appl. \& Environmental Microbiology & 103 & 0.48 & Acta Horticulturae & 49 & 0.23 & Science & 32 & 0.15 \\
\hline Environmental Science \& Technology & 99 & 0.46 & Cahiers De Biologie Marine & 49 & 0.23 & Ocean Engineering & 31 & 0.14 \\
\hline Journal of Chromatography A & 96 & 0.45 & Journal of Biogeography & 48 & 0.22 & Marine Technology and Engineering & 31 & 0.14 \\
\hline Atmospheric Environment & 93 & 0.43 & Journal of Phycology & 47 & 0.22 & Microbial Ecology & 31 & 0.14 \\
\hline Deep Sea Research Part II & 88 & 0.41 & Aquatic Botany & 47 & 0.22 & Analytical Chemistry & 31 & 0.14 \\
\hline Ecological Indicators & 86 & 0.40 & Tectonophysics & 46 & 0.21 & Int. J. Environmental Analytical Chemistry & 30 & 0.14 \\
\hline Aquatic Microbial Ecology & 85 & 0.39 & Proc. Int. Society for Optical Engineering & 46 & 0.21 & Journal of Hydrology & 30 & 0.14 \\
\hline Ocean and Coastal Management & 85 & 0.39 & Marine Drugs & 46 & 0.21 & Environmental Science and Pollution Res. & 30 & 0.14 \\
\hline Toxicon & 84 & 0.39 & Helgoland Marine Research & 45 & 0.21 & Paleoceanography & 30 & 0.14 \\
\hline Analytica Chimica Acta & 80 & 0.37 & J. of Geophysical Research Atmospheres & 45 & 0.21 & Journal of Shellfish Research & 30 & 0.14 \\
\hline Progress in Oceanography & 79 & 0.37 & Europ. Space Agency Sp. Publ. ESA & 45 & 0.21 & Journal of Bacteriology & 29 & 0.13 \\
\hline Journal of Sea Research & 79 & 0.37 & Int. Geoscience \& Remote Sensing Symp. & 45 & 0.21 & Desalination & 29 & 0.13 \\
\hline Limnology and Oceanography & 79 & 0.37 & Organic Geochemistry & 45 & 0.21 & Cybium & 29 & 0.13 \\
\hline J. Geophysical Research C Oceans & 77 & 0.36 & Environmental Toxicology and Chemistry & 45 & 0.21 & Ardeola & 28 & 0.13 \\
\hline Geomorphology & 74 & 0.34 & Estuaries and Coasts & 42 & 0.19 & Facies & 28 & 0.13 \\
\hline Journal of Fish Biology & 72 & 0.33 & Proc. Int. Conf. Off. Mechanics \& Arctic Engin. & 42 & 0.19 & Lecture Notes in Computer Science & 28 & 0.13 \\
\hline Ecotoxicology and Environmental Safety & 71 & 0.33 & Wit Transactions on Ecol. \& Environment & 41 & 0.19 & European Journal of Phycology & 28 & 0.13 \\
\hline Env. Monitoring and Assessment & 70 & 0.32 & Zootaxa & 40 & 0.19 & BMC Evolutionary Biology & 28 & 0.13 \\
\hline Molecular Ecology & 68 & 0.32 & Geo Marine Letters & 40 & 0.19 & Aquatic Living Resources & 28 & 0.13 \\
\hline Boletín Geológico y Minero & 66 & 0.31 & Bolleti Societat Historia Natural Balears & 40 & 0.19 & Journal of Agricultural and Food Chemistry & 27 & 0.13 \\
\hline Arch. Env. Contamination and Toxicol. & 65 & 0.30 & Proc. National Academy of Sciences USA & 40 & 0.19 & Holocene & 27 & 0.13 \\
\hline Quaternary Science Reviews & 65 & 0.30 & Systematic and Applied Microbiology & 40 & 0.19 & Parasitology Research & 27 & 0.13 \\
\hline Marine Ecology & 63 & 0.29 & Aquaculture Research & 39 & 0.18 & Biological Journal of the Linnean Society & 27 & 0.13 \\
\hline Deep Sea Research Part I & 63 & 0.29 & Sedimentology & 39 & 0.18 & Bioresource Technology & 26 & 0.12 \\
\hline Acta Oecologica & 62 & 0.29 & Natural Hazards and Earth System Science & 39 & 0.18 & Others & 11769 & 54.57 \\
\hline $\begin{array}{l}\text { Int. J. of Systematic and Evolutionary } \\
\text { Microbiology }\end{array}$ & 62 & 0.29 & Biological Invasions & 39 & 0.18 & Total & 21565 & 100.00 \\
\hline Water Air and Soil Pollution & 62 & 0.29 & Nature & 38 & 0.18 & & & \\
\hline
\end{tabular}

within this legislation worldwide need technological development supported with job opportunities. This author proposes a series of thematic areas to which marine research can play an active role in developing new products.

\subsection{The ecosystem-based approach: a challenge for integration}

As commented above, Portuguese and Spanish scientists have played an important role in implementing the WFD (an example can be seen in the number of assessment methods developed in these countries: Birk et al. (2012)). Now, they are also participating in implementing the MSFD, in which the main objective is to maintain a good environmental status for marine waters, habitats and resources, delivering an integrated ecosystem-based approach. The need of studying multiple components of the ecosystem, together with the integration of the information, makes the MSFD as an important area of research (Borja et al., 2011). In this particular case, while we have a good knowledge of the structural aspects of marine systems and associated study methods (see Birk et al., 2012), our knowledge of the ecosystem functioning, resilience and threshold effects is scarce and the methods and indices for their study are more uncertain and require to be investigated (Borja et al., 2010a; Folke et al., 2002). In addition, the use of models (e.g. hydrodynamic, habitat suitability models, ecosystem models, etc.) will be of importance for an adequate management of marine waters.

\subsection{Human activities and impacts to the ecosystem: need of a Marine Spatial Planning}

Human activities are producing increasing impacts in marine ecosystems (Halpern et al., 2008), which usually are cumulative and need 
Table 3

Most frequent keywords used by Portuguese and Spanish scientists, between 1974 and 2012 (consulted in SCOPUS, on 3rd February 2013).

\begin{tabular}{|c|c|c|c|c|c|c|c|c|}
\hline Keywords & Papers & $(\%)$ & Keywords & Papers & $(\%)$ & Keywords & Papers & $(\%)$ \\
\hline Animal(s) & 3446 & 6.80 & Seasonal variation & 578 & 1.14 & Heavy metals & 402 & 0.79 \\
\hline Water pollutants(tion) & 2501 & 4.93 & Oceanography & 571 & 1.13 & Species diversity & 396 & 0.78 \\
\hline Coastal zone(s)/waters & 2154 & 4.25 & Taxonomy & 559 & 1.10 & Chemistry & 394 & 0.78 \\
\hline Mediterranean Sea & 1933 & 3.81 & Bioaccumulation & 550 & 1.08 & Community structure & 391 & 0.77 \\
\hline Estuary(es)-environment & 1903 & 3.75 & Climate change & 542 & 1.07 & Sampling & 373 & 0.74 \\
\hline Sediment(s) & 1882 & 3.71 & Metabolism & 536 & 1.06 & Upwelling & 369 & 0.73 \\
\hline Atlantic Ocean & 1785 & 3.52 & Copper & 517 & 1.02 & Temperature & 367 & 0.72 \\
\hline Seawater & 1681 & 3.32 & Salinity & 503 & 0.99 & Diet & 362 & 0.71 \\
\hline Environmental monitoring & 1408 & 2.78 & Nucleotide sequence & 499 & 0.98 & Coastal lagoon & 355 & 0.70 \\
\hline Fish-Pisces & 1370 & 2.70 & Lead & 464 & 0.92 & Physiology & 339 & 0.67 \\
\hline Algae & 1228 & 2.42 & Numerical model & 452 & 0.89 & Computer simulation & 336 & 0.66 \\
\hline Marine environment & 1168 & 2.30 & Morphology & 450 & 0.89 & Eutrophication & 335 & 0.66 \\
\hline Bacteria & 1102 & 2.17 & Seashore & 449 & 0.89 & Sedimentation & 325 & 0.64 \\
\hline Ecosystem(s) & 901 & 1.78 & Environmental impact & 446 & 0.88 & Anthropogenic effect & 319 & 0.63 \\
\hline Concentration & 874 & 1.72 & Ecology & 444 & 0.88 & Chlorophyll & 314 & 0.62 \\
\hline Mollusca & 864 & 1.70 & Zinc & 441 & 0.87 & Organic matter & 312 & 0.62 \\
\hline Crustacea(n) & 816 & 1.61 & Genetics & 438 & 0.86 & Primary production & 300 & 0.59 \\
\hline Molecular sequence & 724 & 1.43 & Water quality & 436 & 0.86 & Aquaculture & 297 & 0.59 \\
\hline Biomass & 701 & 1.38 & Spatial distribution & 431 & 0.85 & Seagrass & 296 & 0.58 \\
\hline Biodiversity & 686 & 1.35 & Mathematical model & 421 & 0.83 & Remote sensing & 291 & 0.57 \\
\hline Growth (rate) & 654 & 1.29 & Benthos & 407 & 0.80 & Nitrogen & 288 & 0.57 \\
\hline Abundance & 645 & 1.27 & Hydrodynamics & 407 & 0.80 & Risk assessment & 286 & 0.56 \\
\hline Phytoplankton & 602 & 1.19 & Cadmium & 406 & 0.80 & Carbon & 280 & 0.55 \\
\hline Phylogeny & 592 & 1.17 & Coastal engineering & 402 & 0.79 & & & \\
\hline
\end{tabular}

research to conserve and manage the oceans (Ban et al., 2010). In addition, the increasing human uses of marine waters (e.g. fisheries, aquaculture, shipping, renewable energies, recreation, mining, etc.) has promoted the discussion about how to appropriately manage the simultaneous need to conserve marine resources and keep our current essential uses (Collie et al., 2013). The approach to find a balance of these two aims is the Marine Spatial Planning (Ehler and Douvere, 2009). With the adoption of the new European Marine Spatial Planning and Coastal Management Directive (now in draft), this will be a field of research which is increasing very fast (Qiu and Jones, 2013; Stelzenmüller et al., 2013; Suárez de Vivero and Rodríguez Mateos, 2012).

\subsection{Ecosystem services: is there a price for using marine resources?}

It is well known that marine ecosystems provide numerous goods and services (Barbier et al., 2012), such as biogeochemical services (e.g. carbon sequestration), nutrient cycling, coastal protection (e.g. provided by coral reefs), food provision, etc. (Costanza et al., 1997). Despite the important role of such goods and services, their study and their associated monetary value is still limited and, although some studies have been undertaken in Iberian seas (e.g. Murillas-Maza et al., 2011;
Pinto et al., 2013a, 2013b) much more research is needed for a better management of the oceans.

\subsection{From fisheries to aquaculture}

Spain and Portugal have good research records in fisheries. Since the 1980 's both countries, and especially Spain, are leading some aquaculture production, in shellfish and fishes. In this way, Iberian scientists have been involved in different topics of aquaculture research, from new species, new products, better production practices, to environmental impacts. Now, there is also place to investigate the reduction of impacts and implement new sustainable aquaculture methods, including multitrophic approaches (Aguado-Giménez et al., 2012; Quintino et al., 2012; Ruiz et al., 2010; Sanz-Lázaro and Marín, 2006), and the adaptation both of fisheries and aquaculture to climate change (Merino et al., 2012).

\subsection{Global change: from studying impacts to adaptation and mitigation}

The oceans are changing rapidly due to human actions (Halpern et al., 2008). Surface waters are warming, sea-level rise is accelerating

Table 4

Some key research topics identified in recent times at different scales. ICES: International Council for the Exploration of the Sea (ICES).

\begin{tabular}{|c|c|c|c|c|c|c|}
\hline \multirow[t]{2}{*}{ Research topics } & \multirow{2}{*}{$\begin{array}{l}\text { European Commission (2012) } \\
\text { Europe }\end{array}$} & \multirow{2}{*}{$\frac{\text { ICES (2013) }}{\text { Europe }}$} & \multirow{2}{*}{$\frac{\text { Rees et al. (2013) }}{\text { United Kingdom }}$} & \multirow{2}{*}{$\frac{\text { Fissel et al. (2012) }}{\text { Canada }}$} & \multirow{2}{*}{$\begin{array}{l}\text { Rudd and Lawton (2013) } \\
\text { Global topics }\end{array}$} & \multirow{2}{*}{$\frac{\text { This paper }}{\text { Iberian }}$} \\
\hline & & & & & & \\
\hline Marine observation, data collection, monitoring & $\mathrm{X}$ & $\mathrm{X}$ & $\mathrm{X}$ & $\mathrm{X}$ & $\mathrm{X}$ & $\mathrm{X}$ \\
\hline Climate change adaptation & $\mathrm{X}$ & & & $\mathrm{X}$ & & $\mathrm{X}$ \\
\hline Informing management and governance & $\mathrm{X}$ & & $\mathrm{X}$ & $\mathrm{X}$ & $\mathrm{X}$ & $\mathrm{X}$ \\
\hline Ecosystem processes and dynamics & & $\mathrm{X}$ & & $\mathrm{X}$ & $\mathrm{X}$ & \\
\hline Ecosystem pressures and impacts & & $\mathrm{X}$ & & $\mathrm{X}$ & & \\
\hline Integrated ecosystem-based assessment & & $\mathrm{X}$ & & & & $\mathrm{X}$ \\
\hline Ecosystem services & & & $\mathrm{X}$ & & & $\mathrm{X}$ \\
\hline Marine Spatial Planning & & & $\mathrm{X}$ & & $\mathrm{X}$ & $\mathrm{X}$ \\
\hline Maritime policy and citizenship & & & $\mathrm{X}$ & & $\mathrm{X}$ & $\mathrm{X}$ \\
\hline Marine conservation & & & $\mathrm{X}$ & & & $\mathrm{X}$ \\
\hline Contaminants & & & & & $\mathrm{X}$ & \\
\hline Mineral resource extraction & & & & & $\mathrm{X}$ & \\
\hline Fisheries and aquaculture & & & & & & $\mathrm{X}$ \\
\hline Restoration & & & & & & $\mathrm{X}$ \\
\hline
\end{tabular}


and the oceans are becoming increasingly acidic. These 'new' anthropogenic factors are affecting marine ecosystems in the Iberian Peninsula (Chust et al., 2011; Gómez-Gesteira et al., 2011; Vargas Yáñez et al., 2008) which, in many areas, have already been significantly weakened by overfishing, contamination, invasive species and other human-induced influences. Such factors will introduce changes in communities' composition and probably in food webs and ecosystems stability, resilience, and functioning. However, our understanding of the linkages between anthropogenic disturbances, biological diversity, ecosystem services, functionality, and the resilience of marine ecosystems needs to be improved (Narayanaswamy et al., 2013; Pinto et al., 2013b). In fact, for some ecosystem components such as macroalgae, investigating the combined effects of human pressures (e.g., exploitation and wastewater discharges) and environmental variables (e.g., light, waves, temperature), over long-term series, Borja et al. (2013) demonstrated that, in impacted areas macroalgae are more vulnerable to environmental changes and its resilience is more reduced. Currently, there is an insufficient policy, inadequate research and management funding, and gaps in scientific knowledge. For example, it will be necessary for future marine research to increase knowledge on the combined effects of concurrent climate and non-climate stressors and their effects on species interactions and responses at assemblage and ecosystem levels (Olabarria et al., 2012; Wernberg et al., 2012). Intensive monitoring is also a precondition for the further development of coupled ecosystem-global change models, as demonstrated by the above example of macroalgae in Spain. In addition, development of models, scenarios and adaptation measures to global changes are also needed (Ciscar et al., 2011; Nicholls et al., 2012; Tobey et al., 2010).

\subsection{Restoration: recovering structure and functioning}

Iberian coasts and estuaries have experienced important degradation throughout the 20th Century (Marcos et al., 2009). Hence, ecological restoration is becoming an increasingly important tool to manage, conserve, and repair damaged ecosystems, with significant advances in the past few decades (Hobbs, 2007). Therefore, measuring restoration at community level is neither fast nor easy, and requires a focus on restoration of community function, e.g., habitat reconstruction, species interactions, trophic structure, rather than a focus on the restoration of particular species (Borja et al., 2010b; Verdonschot et al., 2013). Thus, restoration efforts should rely on what is known from theoretical and empirical research on how communities develop and are structured through time. Some areas of community theory (e.g. dispersal/ colonisation dynamics, patch dynamics, metapopulations theory) and recovery processes are poorly understood and thus research in these areas will benefit both basic ecology and restoration practices, providing evidence of how this ecological knowledge might enhance restoration success (Verdonschot et al., 2013). Further research is also needed to identify restoration thresholds and develop corrective methodologies to overcome such thresholds.

\subsection{Conservation: Marine Protected Areas as important management tools}

Marine Protected Areas (MPAs) are an important tool for enhancing the resilience and adaptive capacity of ecosystems (García-Charton et al., 2008). They are also important because they allow mitigation of anthropogenic factors, such as overfishing or habitat destruction within their boundaries, by means of management or prohibition (Mumby et al., 2006). Not only MPAs, but also protection of near-natural ecosystems is a very good strategy for managing climate change-related stressors and biodiversity (Heller and Zavaleta, 2009).

Probably, in addition to the abovementioned research priorities, other research needs could be raised in coming years by the Iberian scientific community. In this Special Issue there are some examples of such new topics, which show the evolution and quality of Iberian investigation in recent years. However, as Bernard de Chartres (13th Century) said, we build science over the shoulder of giants, represented by those individuals who, after the 15th Century sailed the world seas, looking for new opportunities. We are convinced that this is now the opportunity for the Iberian research: make it every day more international and more excellent.

\section{Acknowledgements}

This is contribution number 643 from AZTI-Tecnalia (Marine Research Division).

\section{References}

Aguado-Giménez, F., Piedecausa, M.A., Gutiérrez, J.M., García-Charton, J.A., Belmonte, A., García-García, B., 2012. Benthic recovery after fish farming cessation: a "beyond-BACI" approach. Marine Pollution Bulletin 64, 729-738.

Ban, N.C., Alidina, H.M., Ardron, J.A., 2010. Cumulative impact mapping: advances, relevance and limitations to marine management and conservation, using Canada's Pacific waters as a case study. Marine Policy 34, 876-886.

Barbier, E.B., Hacker, S.D., Koch, E.W., Stier, A., Silliman, B., 2012. Estuarine and Coastal Ecosystems and Their Services. Chapter 6. In: van den Belt, M., Costanza, R. (Eds.), Ecological Economics of Estuaries and Coasts. In: Wolanski, E., McLusky, D. (Eds.), Treatise on Estuarine and Coastal Science, vol. 12. Academic Press, Waltham, MA.

Birk, S., Bonne, W., Borja, A., Brucet, S., Courrat, A., Poikane, S., Solimini, A., van de Bund, W., Zampoukas, N., Hering, D., 2012. Three hundred ways to assess Europe's surface waters: an almost complete overview of biological methods to implement the Water Framework Directive. Ecological Indicators 18, 31-41.

Borja, Á., 2011. Open your minds: technological development and job opportunities from marine environmental legislation. Marine Pollution Bulletin 62, 1-2.

Borja, A., Elliott, M., 2013. Marine monitoring during an economic crisis: the cure is worse than the disease. Marine Pollution Bulletin 68, 1-3.

Borja, Á., Elliott, M., Carstensen, J., Heiskanen, A.-S., van de Bund, W., 2010a. Marine management - towards an integrated implementation of the European Marine Strategy Framework and the Water Framework Directives. Marine Pollution Bulletin 60, 2175-2186

Borja, Á., Dauer, D., Elliott, M., Simenstad, C., 2010b. Medium- and long-term recovery of estuarine and coastal ecosystems: patterns, rates and restoration effectiveness. Estuaries and Coasts 33, 1249-1260.

Borja, Á. Galparsoro, I., Irigoien, X., Iriondo, A., Menchaca, I., Muxika, I., Pascual, M. Quincoces, I., Revilla, M., Germán Rodríguez, J., Santurtún, M., Solaun, O., Uriarte, A., Valencia, V., Zorita, I., 2011. Implementation of the European Marine Strategy Framework Directive: a methodological approach for the assessment of environmental status, from the Basque Country (Bay of Biscay). Marine Pollution Bulletin 62, 889-904.

Borja, A., Fontán, A., Muxika, I., 2013. Interactions between climate change and human pressures upon a macroalgae population: implications for management. Ocean \& Coastal Management 76, 85-95.

Chust, G., Borja, Á., Caballero, A., Irigoien, X., Sáenz, J., Moncho, R., Marcos, M., Liria, P., Hidalgo, J., Valle, M., Valencia, V., 2011. Climate change impacts on coastal and pelagic environments in the southeastern Bay of Biscay. Climate Research 48, 307-332.

Ciscar, J.C., Iglesias, A., Feyen, L., Szabó, L., van Regemorter, D., Nicholls, R., Watkiss, P., Christensen, O.B., Dankers, R., Garrote, L., Amelung, B., Goodess, C.M., Moreno, A., Richards, J., Soria, A., Hunt, A., 2011. Physical and economic consequences of climate change in Europe. PNAS 108, 2678-2683.

Collie, J.S., Adamowicz, W.L., Beck, M.W., Craig, B., Essington, T.E., Fluharty, D., Rice, J., Sanchirico, J.N., 2013. Marine spatial planning in practice. Estuarine, Coastal and Shelf Science 117, 1-11.

Colmeiro, M., 1889. Enumeración de las Criptógamas de España y Portugal. II. Revista Progr. Ciencias, Madrid. , 16-17 1-160.

Costanza, R., d'Arge, R., de Groot, R., Farber, S., Grasso, M., Hannon, B., Limburg, K., Naeem, S., O'Neill, R.V., Paruelo, J., Raskin, R.G., Sutton, P., van den Belt, M., 1997. The value of the world's ecosystem services and natural capital. Nature 387, 253-260.

De Buen, O., 1886. Materiales para la fauna carcinológica de España. Anales de la Sociedad Española de Historia Natural 16, 405-434.

De Buen, F., 1942. Fauna ictiológica. Catálogo de peces ibéricos. Boletín de la Real Sociedad española de Historia Natural 40 (80 pp.).

Delgado, M.J., Duarte, C.M., Tintoré, J., Parrilla, G., 1999. El pulso de las Ciencias Marinas en España. Dirección General de Enseñanza Superior e Investigación Científica. Ministerio de Educación y Cultura, Madrid84-00-07963-9 (134pp.).

Duarte, C.M., Acuña, J.L., Álvarez, X.A., Blasco, D., Bordons, M., Costas, R., Dañobeitia, J.J., Hernández, S., Losada, I.J., Morales, B., Nombela, M.A., Ruiz, J., Zanuy, S., 2006. Las Ciencias y Tecnologías Marinas en España. Informes CSIC (296 pp.)

Ehler, C., Douvere, F., 2009. Marine Spatial Planning: A Step-by-step Approach Toward Ecosystem-Based Management. Intergovernmental Oceanographic Commission and Man and the Biosphere Programme. IOC Manual and Guides No. 53, ICAM Dossier No. 6. UNESCO, Paris (99 pp.).

European Commission, 2012. Green Paper - Marine Knowledge 2020 from Seabed Mapping to Ocean Forecasting. Brussels 29.8.2012 COM (2012) 473 final (19 pp.).

Ferrer-Hernández, F., 1914a. Esponjas del Cantábrico (Parte 1aㅗ: Calcarea, Euceratosa). Trabajos del Museo Nacional de Ciencias Naturales (Zoología) 14, 1-36.

Ferrer-Hernández, F., 1914b. Esponjas del Cantábrico (Parte 2ª̣: Myxospongida, Tetraxonida, Triaxonida). Trabajos del Museo Nacional de Ciencias Naturales (Zoología) 17, 1-46. 
Fissel, D., Babin, M., Bachmayer, R., Denman, K., Dewailly, E., Gillis, K.M., Fortier, L. Hyndman, R., Lane, D., Lewis, M., Macdonald, R., Moran, K., Neis, B., Nuttall, M. Pelletier, É., Ridgeway, L., Roussel, S., Snelgrove, P., Sutherland, W.J., Suttle, C., Wallace, D., Wiber, M.G., 2012. 40 Priority Research Questions for Ocean Science in Canada. A Priority-setting Exercise by the Core Group on Ocean Science in Canada. The Council of Canadian Academies (25 pp., www.scienceadvice.ca/en/assessments/ other/ocean_science_phase_one.aspx).

Folke, C., Carpenter, S., Elmqvist, T., Gunderson, L., Holling, C.S., Walker, B., 2002 Resilience and sustainable developmente: building adaptative capacity in a world of transformations. Ambio 31, 437-440.

Freire, J., Fernández, L., Muiño, R., 2006. Role of the Spanish scientific community in the initial assessment and management of the environmental damages caused by the Prestige oil spill. Marine Policy 30, 308-314.

García-Charton, J.A., Pérez-Ruzafa, A., Marcos, C., Claudet, J., Badalamenti, F., BenedettiCecchi, L., Falcón, J.M., Milazzo, M., Schembri, P.J., Stobart, B., Vandeperre, F., Brito, A., Chemello, R., Dimech, M., Domenici, P., Guala, I., Le Diréach, L., Maggi, E., Planes, S., 2008. Effectiveness of European Atlanto-Mediterranean MPAs: do they accomplish the expected effects on populations, communities and ecosystems? Journal for Nature Conservation 16, 193-221.

Gómez-Gesteira, M., Gimeno, L., deCastro, M., Lorenzo, M.N., Alvarez, I., Nieto, R., Taboada, J.J., Crespo, A.J.C., Ramos, A.M., Iglesias, I., Gómez-Gesteira, J.L., Santo, F.E., Barriopedro, D., Trigo, I.F., 2011. The state of climate in NW Iberia. Climate Research $48,109-144$

Halpern, B.S., Walbridge, S., Selkoe, K.A., Kappel, C.V., Micheli, F., D'Agrosa, C., Bruno, J.F., Casey, K.S., Ebert, C., Fox, H.E., Fujita, R., Heinemann, D., Lenihan, H.S., Madin, E.M.P., Perry, M.T., Selig, E.R., Spalding, M., Steneck, R., Watson, R., 2008. A global map of human impact on marine ecosystems. Science 319, 948-952.

Heller, N.E., Zavaleta, E.S., 2009. Biodiversity management in the face of climate change: a review of 22 years of recommendations. Biological Conservation 142, 14-32.

Hidalgo, J.G., 1917. Fauna malacológica de España, Portugal y las islas Baleares. Moluscos testáceos marinos. Trabajos del Museo Nacional Ciencias Naturales, Serie Zoológica, no 30. Madrid. (752 pp.).

Hobbs, R.J., 2007. Setting effective and realistic restoration goals: key directions for research. Restoration Ecology 15, 354-357.

ICES, 2013. Science Draft Plan 2014-2018.

Lázaro-Ibiza, B., 1889. Datos para la flora algológica del Norte y Noroeste de España. Anales de la Sociedad Española de Historia Natural 18, 275-294.

Lázaro-Ibiza, B., 1893. Contribuciones a la flora de la Península Ibérica. Notas críticas acerca de la flora española (primera serie). Anales de la Sociedad Española de Historia Natural 22, 19-46

Lozano Rey, L., 1928. et sec. Peces de la fauna Ibérica. Tomo I: Junta de Ampliación de Estudios, 1928. 692 pp. Tomos II a IV: Real Academia de Ciencias, Madrid (1947 (839 pp.), 1952 (613 pp.), 1960 (613 pp.)).

Marcos, P., del Río, S., Barea, J., Caballero, M.J., 2009. Destrucción a toda costa. Situación del litoral español y sus espacios protegidos. Greenpeace (279 pp.).

Margalef, R., 1977. Ecología. Omega Editorial, Barcelona (951 pp.).

Marques, J.C., Basset, A., Brey, T., Elliot, M., 2009. The ecological sustainability trigon - a proposed conceptual framework 4 for creating and testing management scenarios. Marine Pollution Bulletin 58, 1773-1779.

Merino, G., Barange, M., Blanchard, J.L., Harle, J., Holmes, R., Allen, I., Allison, E.H., Badjeck, M.C., Dulvy, N.K., Holt, J., Jennings, S., Mullon, C., Rodwell, L.D., 2012. Can marine fisheries and aquaculture meet fish demand from a growing human population in a changing climate? Global Environmental Change 22, 795-806.

Minster, J.F., Connolly, N., 2006. Navigating the future - III updated synthesis of perspectives on marine science and technology in Europe. European Science Foundation, Position Paper 8 (71 pp.)

Mumby, P.J., Dahlgren, C.P., Harborne, A.R., Kappel, C.V., Micheli, F., Brumbaugh, D.R., Holmes, C.E., Mendes, J.M., Broad, K., Sanchirico, J.N., Buch, K., Box, S., Stoffle, R.W., Gill, A.B., 2006. Fishing, trophic cascades, and the process of grazing on coral reefs. Science 311, 98-101.

Murillas-Maza, A., Virto, J., Gallastegui, M.C., González, P., Fernández-Macho, J., 2011. The value of open ocean ecosystems: a case study for the Spanish exclusive economic zone. Natural Resources Forum 35, 122-133.
Narayanaswamy, B.E., Coll, M., Danovaro, R., Davidson, K., Ojaveer, H., Renaud, P.E., 2013. Synthesis of knowledge on marine biodiversity in European seas: from census to sustainable management. PLoS One 8, e58909.

Nicholls, R.J., Woodroffe, C.D., Burkett, V., Hay, J., Wong, P.P., Nurse, L., 2012. Scenarios for coastal vulnerability assessment. Chapter 14 . In: van den Belt, M., Costanza, R. (Eds.), Ecological Economics of Estuaries and Coasts. In: Wolanski, E., McLusky, D. (Eds.), Treatise on Estuarine and Coastal Science, vol. 12. Academic Press, Waltham, MA, pp. 289-303.

Niell, F.X., Ros, J.D. (Eds.), 1982. Actas del Primer Simposio Ibérico de Estudios del Bentos Marino (San Sebastián, abril 1979). Publicaciones de la Universidad del País Vasco, Bilbao.

Nobre, A., 1936. Moluscos marinhos de Portugal. Comp. Ed. do Minho; Barcelos (378 pp.)

Olabarria, C., Arenas, F., Viejo, R.M., Gestoso, I., Vaz Pinto, F., Incera, M., Rubal, M., Cacabelos, E., Veiga, P., Sobrino, C., 2012. Response of macroalgal assemblages from rockpools to climate change: effects of persistent increase in temperature and $\mathrm{CO} 2$. Oikos. http://dx.doi.org/10.1111/j.1600-0706.2012.20825.x.

Pinto, R., de Jonge, V.N., Neto, J.M., Domingos, T., Marques, J.C., Patrício, J., 2013a. Towards a DPSIR driven integration of ecological value, water uses and ecosystem services for estuarine systems. Ocean \& Coastal Management 72, 64-79.

Pinto, R., de Jonge, V.N., Marques, J.C., Chainho, P., Medeiros, J.P., Patrício, J., 2013b. Temporal stability in estuarine systems: implications for ecosystem services provision. Ecological Indicators 24, 246-253.

Qiu, W., Jones, P.J.S., 2013. The emerging policy landscape for marine spatial planning in Europe. Marine Policy 39, 182-190.

Quintino, V., Azevedo, A., Magalhães, L., Sampaio, L., Freitas, R., Rodrigues, A.M., Elliott, M. 2012. Indices, multispecies and synthesis descriptors in benthic assessments: intertidal organic enrichment from oyster farming. Estuarine, Coastal and Shelf Science $110,190-201$

Rallo, A., Borja, A., 2004. Marine research in the Basque Country: an historical perspective. In: Borja, A., Collins, M. (Eds.), Oceanography and Marine Environment of the Basque Country. Elsevier Oceanography Series, 70, pp. 3-25.

Rebok, S., 2012. Malaspina 2010: Una aventura para la ciencia. Revista de Occidente 376 27-47.

Rees, S., Fletcher, S., Glegg, G., Marshall, C., Rodwell, L., Jefferson, R., Campbell, M., Langmead, O., Ashley, M., Bloomfield, H., Brutto, D., Colenutt, A., Conversi, A., Earll, B., Hattam, C., Ingram, S., McKinley, E., Mee, L., Oates, J., Peckett, F., Portus, J., Reed, M., Rogers, S. Saunders, J., Scales, K., Wynn, R., 2013. Priority questions to shape the marine and coastal policy research agenda in the United Kingdom. Marine Policy 38, 531-537.

Rioja, E., 1931. Estudio de los Poliquetos de la Península Ibérica. Físíca y Natural, serie Zool.Memorias de la Academia de Ciencias Experimentales, Madrid (471 pp.).

Rudd, M.A., Lawton, R.N., 2013. Scientists' prioritization of global coastal research questions. Marine Policy 39, 101-111.

Ruiz, J.M., Marco-Méndez, C., Sánchez-Lizaso, J.L., 2010. Remote influence of off-shore fish farm waste on Mediterranean seagrass (Posidonia oceanica) meadows. Marine Environmental Research 69, 118-126.

Sanz-Lázaro, C., Marín, A., 2006. Benthic recovery during open sea fish farming abatement in Western Mediterranean, Spain. Marine Environmental Research 62, 374-387.

Stelzenmüller, V., Lee, J., South, A., Foden, J., Rogers, S.I., 2013. Practical tools to support marine spatial planning: a review and some prototype tools. Marine Policy 38, 214-227.

Suárez de Vivero, J.L., Rodríguez Mateos, J.C., 2012. The Spanish approach to marine spatial planning. Marine Strategy Framework Directive vs. EU Integrated Maritime Policy. Marine Policy 36, 18-27.

Tobey, J., Rubinoff, P., Robadue, D., Ricci, G., Volk, R., Furlow, J., Anderson, G., 2010. Practicing coastal adaptation to climate change: lessons from integrated coastal management. Coastal Management 38, 317-335.

Vargas Yáñez, M., García Martínez, M.C., Moya, F., Tel, E., Parrilla, G., Plaza, F., Lavín, A. 2008. Cambio climático en el Mediterráneo español. Temas de Oceanografía, Instituto Español de Oceanografía 1, 1-159.

Verdonschot, P.F.M., Spears, B.M., Feld, C.K., Brucet, S., Keizer-Vlek, H., Borja, A., Elliott, M., Kernan, M., Johnson, R.K., 2013. A comparative review of recovery processes in rivers, lakes, estuarine and coastal waters. Hydrobiologia 704, 453-474.

Wernberg, T., Smale, D.A., Thomsen, M.S., 2012. A decade of climate change experiments on marine organisms: procedures, patterns and problems. Global Change Biology 18 , 1491-1498. 